\title{
Strategi Sharia' Marketing Pick Up Service Koperasi Syariah TKI Artha Mulya Lamongan
}

\author{
Eny Latifah, Devi Azlina Putri \\ Institut Agama Islam Tarbiatut Tholabah Lamongan \\ Email: Eny.Lathifah@gmail.com
}

Naskah diterima 24 Maret 2020, Revisi 30 Maret 2020, Terbit 19 April 2020

\begin{abstract}
Abstrak
DOI: doi.org/10.21107/pamator.v13i1.7161

Tujuan penelitian adalah ingin mengetahui strategi pemasaran yang Islami serta kelemahan dan kelebihan dari Pick Up Service (pelayanan jemput bola) dari costumer (nasabah) kepada koperasi Sariah TKI Artha Mulya dan sebaliknya. Metode penelitian menggunakan pendekatan kualitatif yang bersifat deskriptif atas gambaran Strategi Sharia'Marketing dengan model Pick Up Service pada Islamic Microfinance yang bernama koperasi syariah TKI Artha Mulya yang langsung ditujukan kepada narasumber dengan bantuan alat penelitian yang terkemas dalam triangulasi agar mendapat data yang bisa diketahui kebenaranya. Hasil penelitian adalah 1) strategi pemasaran dengan Pick Up Service untuk Simpanan Barokah Keluarga (SIBERKAH) di Islamic Microfinance Institutions yang bernama Koperasi Syariah Artha Mulya Lamongan memiliki keunikan dibanding yang lain yaitu nasabah diperbolehkan menyimpan uang sisa pengeluaran untuk belanja sebesar lima ratus rupiah atau lebih kedalam sebuah kaleng yang sebelumnya telah disediakan oleh koperasi syariah tersebut, kemudian strategi Pick Up Service sewaktu- waktu akan ada petugas yang mengambilnya dirumah nasabah. 2) Kekurangan dan kendala yang dihadapi oleh Koperasi Syariah TKI Artha Mulya saat melakukan Pick Up Service dari perspektif marketing yaitu membutuhkan tenaga dan waktu yang lebih ekstra di banding dengan nasabah yang datang sendiri ke kantor, dan 3) Keuntungan dan kelebihan yang di dapat Koperasi Syariah TKI Artha Mulya dalam menjalankan Pick Up Service dalam perspektif nasabah adalah nasabah tidak perlu ke kantor, dan loyalitas serta rasa kekeluargaan antar nasabah dengan koperasi syariah semakin erat.
\end{abstract}

Kata Kunci : koperasi syariah, pelayanan jemput bola, strategi pemasaran

\section{PENDAHULUAN}

Lembaga Keuangan Syariah (LKS) adalah lembaga keuangan yang dalam praktik pelaksanaan akad (tranksaksi) ekonominya berdasarkan pada prinsipprinsip syariah atau hukum islam, yang tidak ada unsur bunga atau ribawi, kegiatan yang banyak memfokuskan menarik dan menyalurkan uang dari dan kepada masyarakat (Suma, 2008). Lembaga keuangan mikro syariah memiliki segmen pasar yang sudah jelas, yaitu masyarakatmasyarakat level menengah kebawah. Sehibgga kegiatan lembaga keuangan mikro syariah banyak berpusat disentra-sentra bisnis pada masyarakat level mikro dan menengah. Lembaga keuangan mikro syariah memiliki karakteristik yang dekat dengan masyarakat, bahkan tidak jarang pula lembaga keuangan mikro syariah berusaha untuk bersosialisasi dan datang langsung ke masyarakat untuk menawarkan jasa-jasa yang ditawarkan. Hal tersebut yang membuat lembaga keuangan mikro syariah menjadi populer dan dekat dengan masyarakat (Muhammad, 2010).

Koperasi merupakan salah satu badan usaha yang berbadan hukum dengan usaha yang beranggotakan orang -orang yang berorientasi menghasilkan nilai tambah yang dapat dimanfaatkan bagi peningkatan kesejahteraan anggotanya. Selain itu, koperasi juga sebagai gerakan ekonomi rakyat yang berorientasi untuk menumbuhkan partisipatif masyarakat dalam upaya memperkokoh struktur perekonomian nasional dengan demokrasi ekonomi yang berdasarkan atas asas kekeluargaan. Banyak jenis koperasi yang didasarkan pada kesamaan kegiatan dan kepentingan ekonomi anggotanya seperti koperasi simpan pinjam.

Koperasi syariah merupakan salah satu lembaga keuangan mikro yang kegiatannya adalah menghimpun dana dari anggota dan menyalurkannya kepada anggota untuk 
mensejahterakan taraf hidup para anggota koperasi maupun masyarakat sekitar dengan menggunakan prinsip yang sesuai dengan prinsip syariah (Kartasapoetra, 2013).

Salah satu koperasi yang saat ini muncul dan berkembang adalah Koperasi Syariah TKI Artha Mulya Sugihan. Koperasi Syariah TKI Artha Mulya merupakan baan usaha yang menyediakan layanan pembiayaan bagi masyarakat maupun penyediaan jasa simpanan. Dengan maksud memberikan kontribusi bagi hadirnya perkembangan ekonomi masyarakat bawah dan memberikan layanan pinjaman dan simpanan dalam meningkatkan kegiatan usaha kecil dengan prinsip syariah. Koperasi Syariah TKI Artha Mulya memiliki kantor cabang diberbagai desa seperti desa Dagan dan Maduran. Dengan berbagai jenis layanan dan produk ang ditawarkan oleh Koperasi Syariah TKI Artha Mulya seperti Simpanan Barokah Keluarga (SIBERKAH).

Kepuasan nasabah terikat dengan kualitas pelayanan dan kualitas pelayanan yang bisa memuaskan pelanggan akan mendorong kepuasan kepada karyawan, kepuasan karyawan akan mendorong bangkitnya loyalitas pada perusahaan. Selanjutnya, loyalitas karyawan akan berdampak pada peningkatan produktivitas, produktifitas karyawan akan menciptakan dan menentukan kepuasan nasabah. Akhirnya, kepuasan nasabah ini akan menciptakan loyalitas nasabah (Al Arif, 2014). Dari tahun ke tahun Koperasi Syariah TKI Artha Mulya mengalami peningkatan signifikan dan semakin padatnya kegiatan nasabah yang bekerja sebagai petani an merangkap juga sebagai pedagang atau kegiatan sehari-hari dihabiskan dengan bekerja dan kesibukan lainya.

Hal ini menjadi perhatian Koperasi Syariah TKI Artha Mulya unuk selalu memberikan inovasi pemasaran terbarunya, baik itu dari sgi produk maupun dari segi layanannya ke nasabah. Koperasi Syariah TKI Artha Mulya memberikan layanan jasa berupa Pick Up Service, yakni layanan antar jemput dana tunai ke nasabah sehingga nasabah tidak perlu untuk datang ke kantor, cukup dengan salah satu pihak marketing untuk mendatangi rumah nasabah sesuai dengan jadwal yang disepakati antara nasabah dengan Koperasi Syariah TKI Artha Mulya. Hal ini bertujuan untuk memotivasi nasabah atau calon nasabah untuk gemar menabung. Hal ini juga termasuk strategi layanan yang diberikan oleh Koperasi kepada nasabah dalam menambah dan menjaga loyalitas nasabah kepada Koperasi Syariah TKI Artha Mulya Desa Sugihan.

\section{METODOLOGI}

Penelitian ini menggunakan metode penelitian kualitatif yang bersifat deskriptif. Dengan analisa deskriptif kualitatif yang memberikan gambaran secara keseluruhan atas permasalahan yang menjadi obyek penelitian (Miles dan Hubberman, 1992). Fokus penelitian ini adalah efektifitas atas Pick Up Service pada Koperasi Syariah TKI Artha Mulya Lamongan dalam mengembangkan produk Simpanan Barokah Keluarga (SIBERKAH). Sumber data didapatkan secara primer dan secara sekunder (Fashri, 2007). Data primer didapatkan oleh penulis melalui wawancara kepada responden dalam hal ini adalah anggota koperasi dan staf dari koperasi syariah. Observasi dilakukan peneliti sebelum lebih dalam menggali informasi terkait permasalahan, dokumentasi di perlukan untuk mengetahui data yang dimiliki oleh pihak koperasi berkaitan dengan keanggotaan, sedangkan intervie dilakukan untuk mengetahui sejauhmana efektifitas dari strategi yang ada baik bagi anggota maupun para staf koperasi.

Peneliti melakukan random dalam penentuan responden dari pihak anggota dan mengambil sampel sebanyak 5 anggota dari 120 jumlah anggota. Karena peneliti lebih terfokus kepada staf PO dan Accounting yang ada di koperasi. Sedangkan data sekunder didapatkan dari berbagai literatur, seperti dari buku, jurnal ilmiah sebelumnya, artikel, dan dari berbagai informasi yang berkaitan dengan strategi pemasaran pada koperasi syariah dalam penggunaan Pick Up Service produk simpanan yang dimilikinya.

Teknik analisis data yang digunakan peneliti adalah dengan melakukan pengecekan secara terus menerus dalam menggali infomasi baik yang di dapat dari responden anggota maupun staf koperasi. Hal itu dilakukan agar bisa mendapatkan data yang riil dengan memadukan alat 
penelitian triangulasi yang berupa observasi, interview dan dokumentasi.

\section{HASIL PEMBAHASAN}

Koperasi syariah TKI Artha Mulya berdiri pada tanggal 17 Agustus 2012 terbentuklah Koperasi Simpan Pinjam Syariah. Kemudian berdasarkan rapat anggota pada tanggal 02 Januari 2015, berubah nama menjadi "Koperasi Artha Mulya" yang bersistem Syariah. Dengan jumlah anggota mencapai 120 orang operasi berjalan dengan sangat baik, dan punya aset 2,5 Milyar Rupiah. hal ini dapat dilihat dengan antusiasnya masyarakat dalam hal tranksaksi baik pinjaman usaha maupun dalam bentuk simpanan.

Strategi pemasaran yang digunakan menggunakan pendekatan pemasaran syariah dengan sistem jemput bola kepada anggota simpanan. Sistematikanya adalah mendatangi anggota kerumah masingmasing. Peneliti hanya menggunakan sebagian kecil anggota untuk dijadikan responden karena lebih terfokus kepada pihak staf dari koperasi syariah. Penggunaan Pick Up Service di koperasi syariah sendiri adalah layanan yang sangat membantu nasabah yang hendak menabung. Nasabah pun merasa sangat terbantu dengan adanya layanan ini tak perlu ke kantor, mengeluarkan tenaga dan waktu yang cukup banyak.

Layanan Pick Up Service ini tak hanya produk tabungan SIBERKAH saja, melainkan juga ada beberapa produk yang menggunakan layanan jasa ini seperti kiriman uang dari luar negeri. Marketing Pick Up Service tidak bisa melakukan penjemputan/pengambilan tabungan setiap hari, dengan tersebar luasnya nasabah di Koperasi Syariah TKI Artha Mulya menjadikan marketing harus mengatur jadwal untuk mendatangi nasabah di beberapa RT tertentu. Pengambilan isi kotak SIBERKAH biasanya dilakukan pada setiap bulan, dan dilakukan pada setiap akhir bulan. Pick Up Service adalah strategi pemasaran yang dilakukan oleh Koperasi Syariah TKI Artha Mulya dengan cara tersebut marketing mendatangi rumah atau toko nasabah. Nasabah cukup dirumah, kemudian marketing mendatangi atau menggambil di tempat nasabah tersebut. Dalam strategi Pick Up Service Koperasi
Syariah TKI Artha Mulya menggunakan dua jenis marketing yang berfungsi sekaligus sebagai jenjang karir karyawan, yaitu : (1) Marketing Collection bertugas mengambil Simpanan Barokah Keluarga (SIBERKAH); (2) Marketing Eksekutif yang bertugas mencari anggota baru; (3) Senior Marketing bertugas menginput data dari keluar masuknya simpanan tersebut. Strategi layanan yang digunakan oleh Koperasi Syariah TKI Artha Mulya juga bermaksud mendekatkan pelayanan karena dominan nasabah atau angotanya merupakan pelaku usaha rumah, dengan hal itu sangat mudah menerapkan strategi Pick Up Service itu sendiri.

Strategi layanan Pick Up Service di Koperasi Syariah TKI Artha Mulya merupakan jasa layanan yang sangat membantu nasabah dalam menabung. Hal ini juga tak luput dari penerapan strategi yang dilakukan Koperasi Syariah TKI Artha. Beberapa strategi tersebut antara lain :

1. Pertama kali pemberian kotak SIBERKAH diberikan sebagai souvenir pada saat pemberian parsel bulan Ramadhan bagi semua anggota koperasi.

2. Setelah itu koperasi Syariah TKI Artha Mulya memperluas dan meningkatkan tingkat promosi karena banyaknya permintaan pada produk SIBERKAH ini.

3. Koperasi Syariah mulai mempromosikan produk dan layanan kepada saudara, teman dan juga lingkungan sekitar khususnya di desa sugihan.

\section{Kelebihan dari Strategi Pick Up Service}

1) Kelebihan strategi ini dari perspektif nasabah, antara lain yaitu : (a) Nasabah tidak perlu untuk datang ke kantor Koperasi Syariah TKI Artha Mulya karena jasa ini menawarkan untuk dijemput ditempat, dirumah maupun ditoko, selain itu tidak akan mengangu pekerjaan karena karyawan Koperasi Artha Mulya yang akan datang sendiri; (b) Nasabah tidak butuh waktu banyak untuk datang ke kantor, karena kebanyakan nasabah memang pekerjaannya dirumah; (c) Dalam menabung, anggota tidak perlu menunggu nominal yang sangat besar agar bisa ditabung, jadi walaupun hanya 500 rupiah bisa ditabung dan dimasukan kedalam kotak SIBERKAH; 
Meningkatkan rasa kekeluargaan di banding menabung di kantor yang sifatnya lebih formal. Karena ketika Pick Up Service komunikasinya atau obrolanya lebih santai di banding saat berada di kantor.

2) Kelebihan strategi ini dari perspektif dari perspektif petugas koperasi adalah : (a) Menjadi ajang silahturahmi dengan nasabah dan juga pihak Koperasi Artha Mulya; (b) Menjadi tempat jalan-jalan, karena jika hanya bekerja di kantor itu akan cepat bosan (c) Menjadi tempat hiburan tersendiri karena haru tawa dengan nasabah yang tipenya humoris; (d) Lebih punya banyak waktu sharing mengenai Koperasi Syariah TKI Artha Mulya baik dari produk maupun informasi lainya mengenai Koperasi Syariah TKI Artha Mulya. Dengan begitu marketing lebih mudah melakukan promosi produk-produk Koperasi Syariah TKI Artha Mulya Sugihan.

\section{Kekurangan dari Strategi Pick Up Service.}

1) Kekurangan strategi ini dari perspektif Nasabah, terdiri dari: (a) Kendalan cuaca yang tidak mendukung seperti hujan, sehingga marketing tidak melakukan Pick Up Service; (b) Dengan banyaknya nasabah yang lebih memilih untuk menggunakan jasa Pick Up Service dari pada datang ke kantor membuat nasabah harus sedikit bersabar untuk menunggu marketing datang mengambilnya. Karena tidak setiap hari nasabah akan didatangi marketing.

2) Dari perspektif Marketing. Terdiri dari: a) Dengan metode menemui nasabah di rumah maupun tempat kerjanya otomatis ini membutuhkan tenaga dan waktu yang lebih ekstra. Berbeda dengan nasabah yang datang ke kantor sendiri. b)Koperasi Syariah TKI Artha Mulya juga membutuhkan marketing banyak karena beda tugas dan fungsinya. Belum juga saat makin banyak berkembangnya nasabah di kemudian hari.

\section{KESIMPULAN}

Pembahasan Strategi Layanan Pick Up Service Pada Produk Simpanan di Koperasi Syariah TKI Artha Mulya Sugihan Lamongan maka dapat diambil kesimpulan bahwa strategi ini pada produk simpanan barokah keluarga (SIBERKAH) di era Society ini mampu memberikan pelayananan dengan memanjakan nasabah dengan penuh ketulusan (saling ridho) serta semakin memperkuat tali persaudaraan dan kekeluargaan antara nasabah dengan lembaga keuangan.

Kekurangan dan kendala yang dihadapi oleh Koperasi Syariah TKI Artha Mulya saat melakukan Pick Up Service dari perspektif marketing yaitu membutuhkan tenaga dan waktu yang lebih ekstra di banding dengan nasabah yang datang sendiri ke kantor. Keuntungan dan kelebihan yang di dapat Koperasi Syariah TKI Artha Mulya dalam menjalankan Pick Up Service dalam perspektif nasabah adalah tidak perlunya nasabah untuk datang ke kantor jika hendak menabung atau mengambil tabungannya.

\section{DAFTAR PUSTAKA}

Al Arif, R \& Nur, M. 2014. Dasar-Dasar Pemasaran Bank Syariah. Jakarta : Alfabeta.

Fashri. 2007. Metodologi Penelitian Kualitatif. Jakarta : PT.Grafindo Persada

Husein, U. 2001. Strategi Manajemen in Action. Jakarta: PT Gramedia Pustaka Utama.

Kartasapoetra, G. 2013. Praktek Pengelolaan Koperasi. Jakarta: Rineka Cipta.

Miles, M.B \& Huberman, M.A. 1992. Analisa Data Kualitatif, Jakarta : UI-Press

Muhammad. 2004 Sistem dan Prosedur Operasional Bank Syariah. Yogyakarta : UII Press.

Rifki, M. 2010. Akuntansi Keuangan Syariah. Yogyakarta: P3EI Press.

Tjiptono, F. 2015. Strategi Pemasaran. Yogyakarta : Andi. 
Latifah, E \& Putri, D.A Strategi Sharia Marketing 159 